\title{
Remarks on the current quality of groundwater in Vietnam
}

\author{
Tran Le Luu ${ }^{1}$
}

Received: 1 January 2017 / Accepted: 26 June 2017 / Published online: 24 July 2017

(C) Springer-Verlag GmbH Germany 2017

\begin{abstract}
This paper reviews the current quality of groundwater in Vietnam. In Vietnam, groundwater is obtained primarily from tubewells, which have high concentrations of pollutants such as $\mathrm{As}, \mathrm{Fe}, \mathrm{Mn}$, and $\mathrm{NH}_{4}{ }^{+}$. In the areas where groundwater tests were conducted, arsenic levels ranged from $0.1-3050 \mu \mathrm{g} / \mathrm{L}$, which substantially exceed the standard of $10 \mu \mathrm{g} / \mathrm{L}$ which has been established by the WHO. Contamination sources are distributed over a large area from the Red River Delta in the north to the Mekong River Delta in the south, putting as many as ten million people at risk of adverse health effects. Levels of arsenic and iron in sediment are strongly correlated, which indicate that the presence of arsenic in groundwater results from the reduction of arsenic bound to iron oxyhydroxides. It is important to raise awareness of these issues among the Vietnamese public by disseminating information about the negative effects of contaminated drinking water, as well as carrying out long-term research projects to identify other sources of contamination and improving water treatment technology and water management capabilities.
\end{abstract}

Keywords Vietnam · Red River - Mekong River · Groundwater $\cdot$ Arsenic $\cdot$ Ferrous $\cdot$ Manganese

Responsible editor: Philippe Garrigues

Tran Le Luu

luu.t1@vgu.edu.vn

1 Department of Mechatronics and Sensor Systems Technology, Vietnamese German University, Hoa Phu Ward, Thu Dau Mot City, Binh Duong Province, Vietnam

\section{Introduction}

Many regions of the world are faced with diminished water resources. (Moglia et al. 2012). This is due to multiple factors such as decreased water supplies, the contamination and overuse of surface and groundwater, and extended periods of low precipitation. From 1950 to the 1990 s, a $100 \%$ increase in the global population, combined with declining quantities of freshwater, resulted in a substantial drop in the per capita availability of water resources, from 17,000 to $70,000 \mathrm{~m}^{3}$ capita $^{-1}$. In addition, as much as $90 \%$ of wastewater is released into the environment untreated, exacting a heavy toll on public health (WHO 2005). The presence of naturally-occurring sediments in drinking water may also introduce toxic substances such as heavy metals. Each year, there are approximately four billion cases of diarrhea, causing 1.8 million fatalities, primarily of children. The overwhelming majority of these cases result from contaminated drinking water, unsanitary conditions, and deficient hygienic practices (Thuy et al. 2015).

Vietnam is a developing country located in Southeast Asia with an area of $329.566 \mathrm{~km}^{2}$, which is shown in Fig. 1 (Moglia et al. 2012). With a population of 90 million in 2011, it is the 13th most populous country in the world (Berg et al. 2001). Seventy percent of the population lives in rural areas, concentrated in the two main agricultural regions of the Red River Delta and Mekong River Delta. Between 2000 and 2010, average daily water consumption in Vietnam increased from 881,100 to $1,079,350 \mathrm{~m}^{3}$ (Moglia et al. 2012). Rapid industrialization and economic growth have led to a massive population shift from the countryside to the cities, creating increased strain on natural resources and the environment (Norrman et al. 2008). The primary sources of water pollution are untreated municipal and industrial wastewater (Chau et al. 2015). Additionally, climate change and global warming may also affect the quality and amount of rainfall, groundwater, 


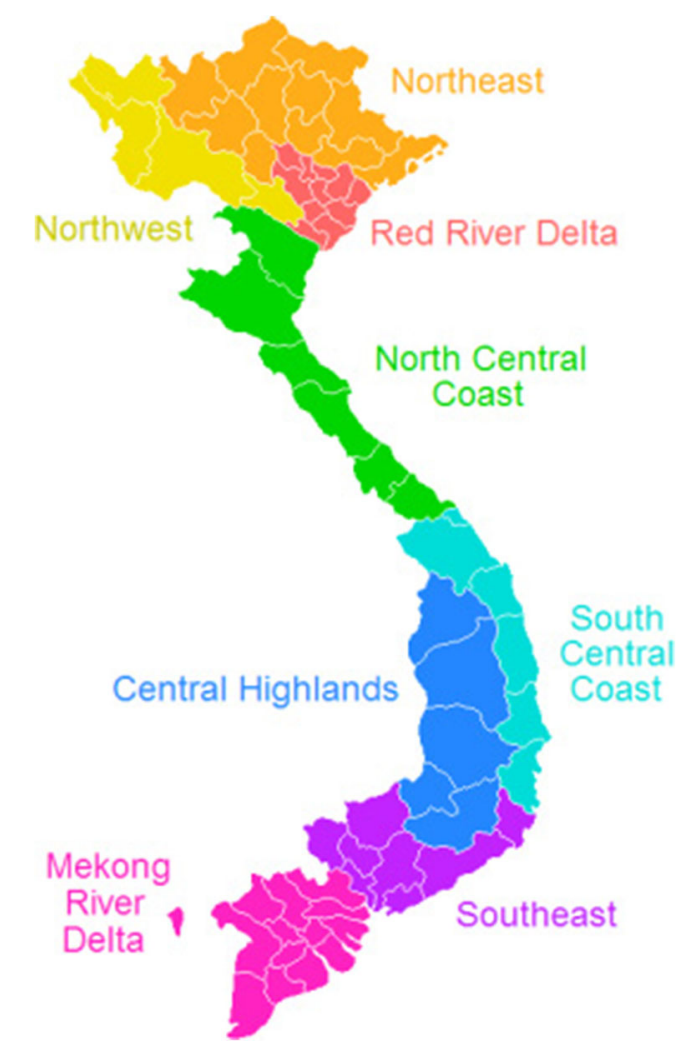

Fig. 1 Vietnam geology map (Moglia et al. 2012)

and surface water. It is therefore urgent to concentrate on environmental protection and the management of natural resources in order to have transition toward sustainable development. There is considerable concern about safe drinking water among the Vietnamese public (McArthur et al. 2012). The exploitation of groundwater for domestic use in Vietnam began roughly 100 years ago with the construction of wells operated by hand pumps. The consumption of polluted groundwater has considerable negative health consequences and can cause serious illnesses of various major organs (WHO 2005). In this paper, the current situation and the impact of environment to the Vietnam groundwater are summarized in detail. Then, the water research and management strategies for the sustainable development also are proposed. Hope it can contribute to the world's water understanding, which is in a serious problem until now and the near future.

\section{The situation in the Red River Delta}

Extending southeast from the national capital, Hanoi (population 11 million), the Red River Delta has an area of $169,000 \mathrm{~km}^{2}$. It has a tropical monsoon climate with a rainy season extending from May to September and a dry season from October to April. Rural residents have switched from using surface water or water from shallow dug wells to using family tubewells from Holocene aquifer and Pleistocene aquifer (Berg et al. 2001) as their primary sources of drinking water. The removal of groundwater from the Pleistocene aquifer causes water to flow down from the Holocene aquifer (Postma et al. 2007). A water-permeable layer of clay several meters thick separates the Holocene and Pleistocene sediments, allowing water to flow between the two aquifers (Smedle et al. 2002). Table 1 shows the arsenic contamination in the aquifers in Hanoi (Berg et al. 2001). Groundwater in Hanoi and its surrounding region is contaminated by high arsenic concentrations in the Holocene and Pleistocene aquifers, which is shown in Fig. 2. This issue raises the question as to whether arsenic mobilization is anthropogenic (Thuy et al. 2015). Arsenic levels exceeded the current WHO standard of $10 \mu \mathrm{g} / \mathrm{L}$ in as many as $72 \%$ of the tubewells included in the study(Agusa et al. 2006) although there was a substantial degree of variation between different areas with concentrations ranging from 0.1 to $3050 \mu \mathrm{g} / \mathrm{L}$ (Berg et al. 2008; Nguyen et al. 2009; Berg et al. 2007; Postma et al. 2010; Agusa et al. 2009; Editorial 2010; Larsen et al. 2008; Nguyen and Itoi 2009; Jessen et al. 2008; Eiche et al. 2008) and an average arsenic concentration from 159 to $430 \mu \mathrm{g} / \mathrm{L}$ (Berg et al. 2001), respectively. The sources of contamination are distributed over a large area in Red River Delta. Figure 3 showed the arsenic contamination in groundwater from the private tubewells (Berg et al. 2001).

Samples of groundwater taken from Hanoi's eight water treatment plants revealed arsenic concentrations of 240 $320 \mu \mathrm{g} / \mathrm{L}$ in three of the plants and $37-82 \mu \mathrm{g} / \mathrm{L}$ in the other five (Berg et al. 2001). Of the 29 tap water samples collected at individual homes (Fig. 2b), 27 had arsenic levels ranging from 7 to $82 \mu \mathrm{g} / \mathrm{L}$ with a mean concentration of $31 \mu \mathrm{g} / \mathrm{L}$. Dissolved arsenic may be binding to iron oxides on the inner surfaces of pipes leading to lower concentrations in the tap water (Agusa et al. 2006). Given the high levels of arsenic found in water from the tubewells ( $48 \%$ above $50 \mu \mathrm{g} / \mathrm{L}$, and $20 \%$ above $150 \mu \mathrm{g} / \mathrm{L}$ ), several million people might be at risk of chronic arsenic poisoning (Berg et al. 2008; Nguyen et al. 2009; Berg et al. 2007). The levels of contamination are comparable to Bangladesh and West Bengal, India; however, the population density is higher (Smedle and Kinniburgh 2002). Arsenic is known to cause diseases of many major organ systems. Moreover, chronic arsenic exposure is correlated with an array of cancers (bladder, kidney, skin, and liver), where inorganic arsenic is more toxic than organic arsenicals (Postma et al. 2010; Agusa et al. 2009; Editorial 2010).

Because of naturally occurring organic matter in the sediments, the groundwater is anoxic and rich in iron. Arsenic concentrations from 25 to $91 \mu \mathrm{g} / \mathrm{L}$ were reduced by up to $80 \%$ by aeration and filtering through sand of arsenic concentration removed to discharge in the Red River delta (Berg et al. 2007) but 50\% samples remained above the Vietnamese drinking water standard of $50 \mu \mathrm{g} / \mathrm{L}$ (Berg et al. 2001). Sediment in the Red River Delta showed a correlation between arsenic and iron levels, which is shown in Fig. 4 
Table 1 Arsenic contamination in the aquifers in Hanoi (Berg et al. 2001)

\begin{tabular}{cccc}
\hline District & Number of sample & Concentration $(\mu \mathrm{g} / \mathrm{l})$ & Range $(\mu \mathrm{g} / \mathrm{l})$ \\
\hline Dong Anh & 48 & 31 & $1-220$ \\
Tu Liem & 48 & 67 & $1-230$ \\
Giai Lam & 55 & 127 & $2-3050$ \\
Thanh Tri & 45 & 432 & $2-3010$ \\
All & 196 & 159 & $1-3050$ \\
\hline
\end{tabular}

(Berg et al. 2001). It is possible that arsenic is bound to iron oxyhydroxides in the sediment and that the reduction of iron when it is dissolved in groundwater causes the arsenic to be released. Arsenic occurring in the sediment is most likely due to the deposition of arsenic-enriched oxyhydroxides which result from erosion and are transported by river currents. Brown to black-brown clay layers showed arsenic concentrations of 6$33 \mathrm{mg} / \mathrm{kg}$ with lower concentrations found in gray clay (2$12 \mathrm{mg} / \mathrm{kg}$ ) and brown to gray sand $(0.6-5 \mathrm{mg} / \mathrm{kg}$ ) (Berg et al. 2001).

The primary form of arsenic found in the groundwater is As(III) with some As(V). Arsenic levels are closely related to levels of ammonium, which is released by the breakdown of organic matter. As(III) concentration peaks in the middle part of the aquifer with a distribution highly similar to that of ammonia and methane. This indicates that there may be a direct relationship between the release of As into the groundwater and the decomposition of organic material. The high alkalinity (up to $810 \mathrm{mg} / \mathrm{L})$ and high nitrogen concentrations (10-48 mg N/L)

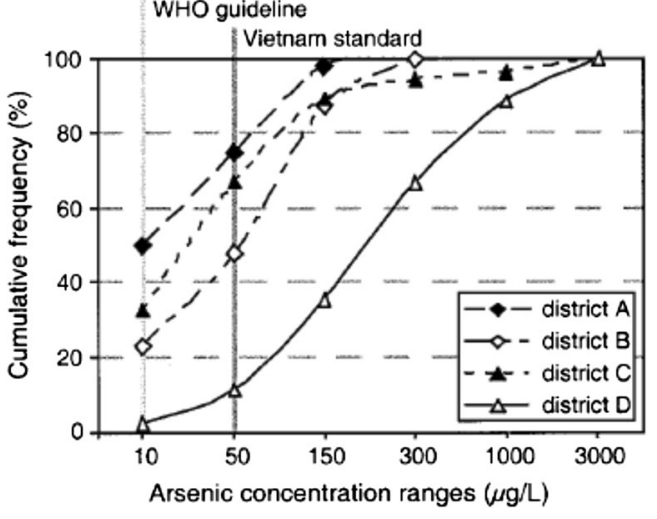

Fig. 3 Arsenic contamination in groundwater from the private tubewells (Berg et al. 2001)

of the groundwater strongly support this possibility (Lawati et al. 2012; Minh et al. 2010; Guilliot et al. 2008).

$$
\begin{aligned}
& \mathrm{H}_{3} \mathrm{AsO}_{3}+\mathrm{H}_{2} \mathrm{O} \leftrightarrow \mathrm{H}_{2} \mathrm{AsO}_{4}{ }^{-}+3 \mathrm{H}^{+}+2 \mathrm{e}^{-} \\
& \mathrm{H}_{3} \mathrm{AsO}_{3}+\mathrm{H}_{2} \mathrm{O} \leftrightarrow \mathrm{HAsO}_{4}^{-}+4 \mathrm{H}^{+}+2 \mathrm{e}^{-} \\
& \mathrm{CH}_{4}+3 \mathrm{H}_{2} \mathrm{O} \leftrightarrow \mathrm{HCO}_{3}{ }^{-}+9 \mathrm{H}^{+}+8 \mathrm{e}^{-}
\end{aligned}
$$

$\mathrm{Fe}$ and $\mathrm{Mn}$ levels in groundwater were higher than those of alkaline earth metals such as $\mathrm{Sr}$ and $\mathrm{Ba}$. Both $\mathrm{Mn}(500 \mathrm{mg} / \mathrm{L})$ and $\mathrm{Ba}(700 \mathrm{mg} / \mathrm{L})$ (WHO 2005) were found in concentrations exceeding the WHO limit for drinking in some samples taken in Hanoi. Groundwater in Hanoi had an average Mn concentration exceeding $1000 \mathrm{mg} / \mathrm{L}$. Seventy percent of the groundwater samples exceeded WHO drinking water guidelines for $\mathrm{Mn}$ and $12 \%$ exceeded those for $\mathrm{Ba}$ of $0.05 \mathrm{mg} / \mathrm{L}$
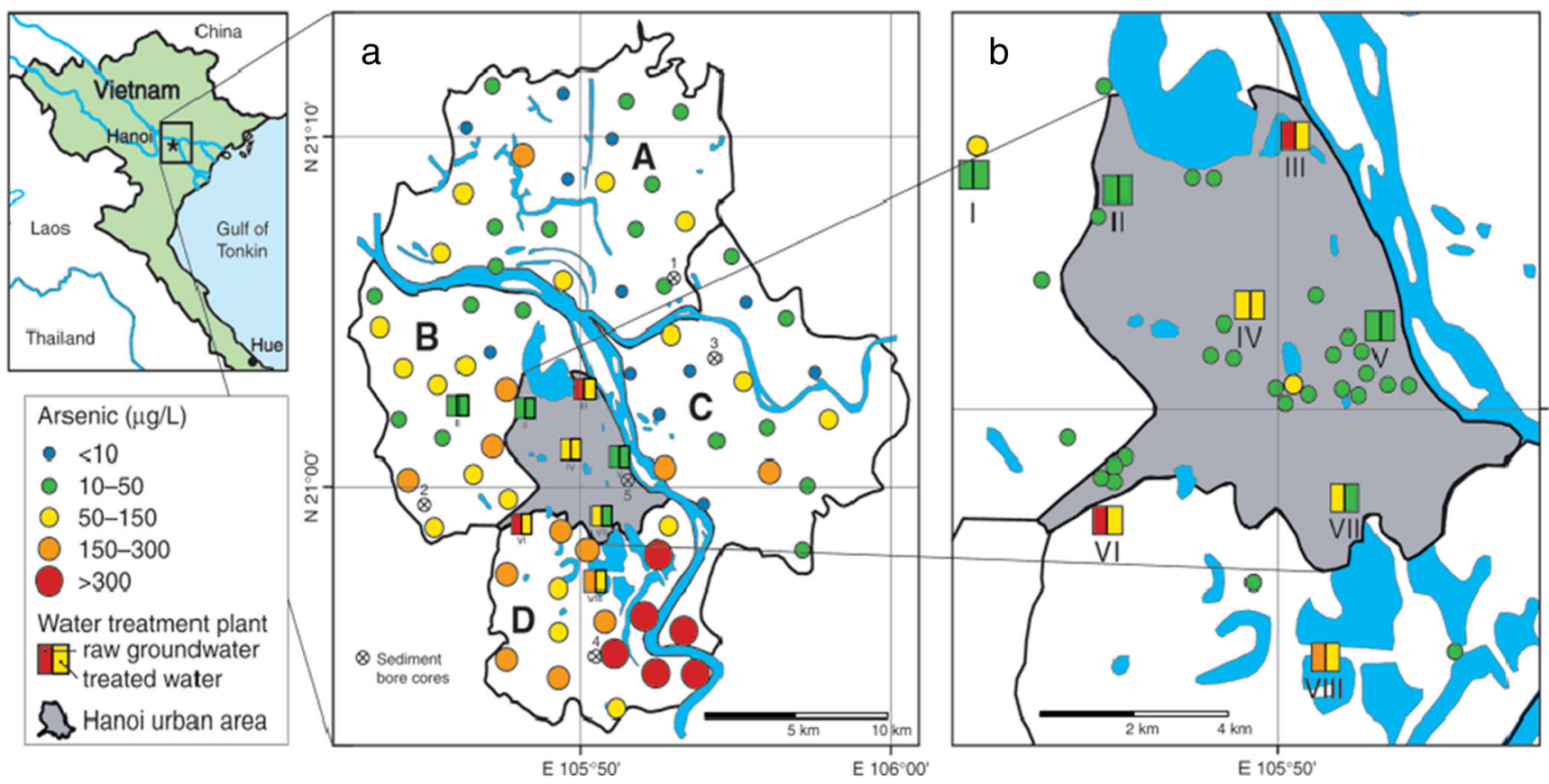

Fig. 2 Arsenic contamination in Hanoi. a In groundwaters pumped from private tubewells. $\mathbf{b}$ In groundwater of the lower aquifer and treated water treatment plants (split rectangles) and tap water of supplied households (dots) (Berg et al. 2001) 


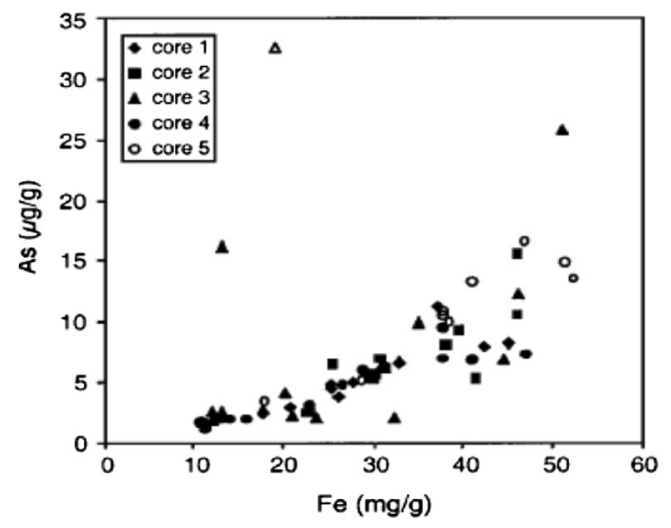

Fig. 4 Correlation between arsenic and iron in sediment core layers in Hanoi (Berg et al. 2001)

(Fig. 5a). Rainwater and surface water in Hanoi also had low concentrations of As. As, Mo, Ga, and Ba concentrations in groundwater showed a strong positive correlation, while there was a negative correlation between concentrations of As and $\mathrm{Pb}$ and $\mathrm{V}$. It is not yet clear what the reasons for these relationships but they may be due to the subsurface geology and geochemistry of the Red River Delta. These results indicate that the use of groundwater in the Red River Delta may be exposing people not only to As but also to other metals like Mn and Ba (Duong et al. 2003).

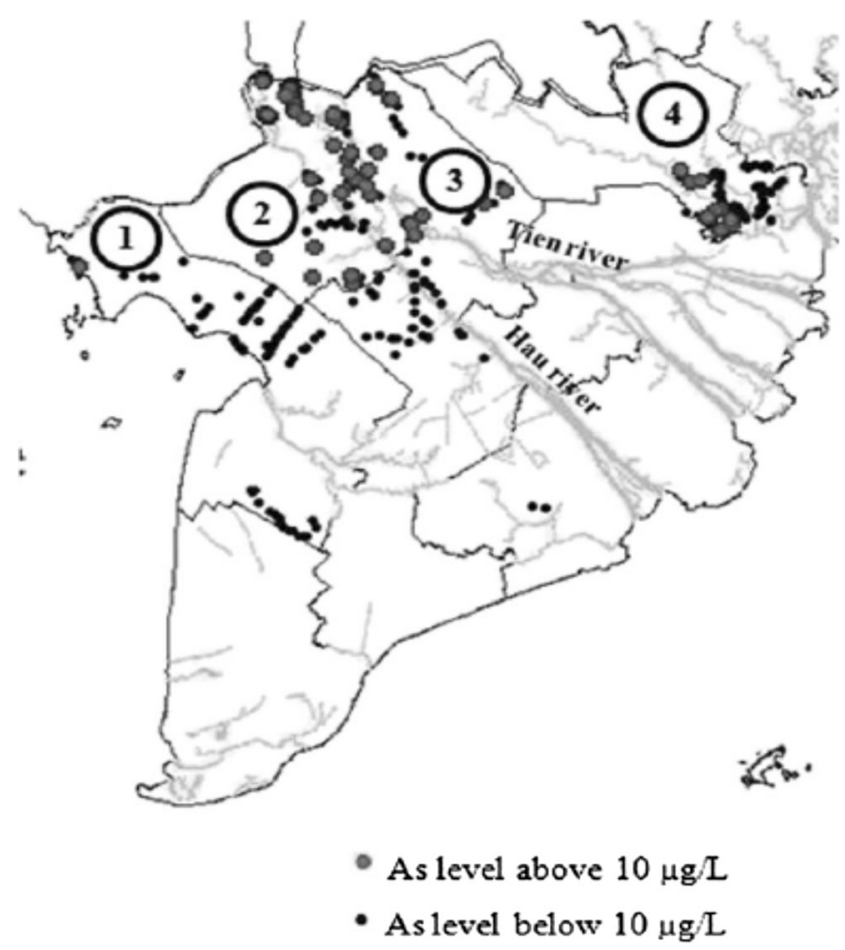

Fig. 5 Arsenic in groundwater of the Mekong River Delta (1) Kien Giang, (2) An Giang, (3) Dong Thap, and (4) Long An (Hoang et al. 2010)

\section{The situation in the Mekong River Delta}

The Mekong River Delta is located in southern Vietnam and neighboring Cambodia, between the East Sea in the southeast and the Gulf of Thailand in the west. The Mekong River Delta consists of two main arteries (the Tien and Hau rivers), which branch into eight smaller rivers. The Mekong River Delta covers an area of $39,713 \mathrm{~km}^{2}$ and contains delta sediments with characteristics similar to the Ganges Plain (Hoang et al. 2010). Low-lying floodplains ( $2 \mathrm{~m}$ above sea level) with highly acidic sulfate soils comprise approximately $60 \%$ of the Mekong Delta. The local climate is tropical monsoonal, with average temperatures of $27-30{ }^{\circ} \mathrm{C}$ and a rainy season lasting from April to November. Local water resources include rainfall, surface water, and groundwater. Household shallow tubewells access groundwater at a depth of 80-120 m (Buschmann et al. 2008). The wells for water supply units and industrial uses access groundwater at a depth of 100-250 m, with $60 \%$ of wells accessing the Pleistocene aquifer. The main trends threatening the sustainability of groundwater in Mekong River Delta are declining groundwater levels and declining groundwater quality.

In a study of 460 wells in the Mekong River Delta, $26 \%$ of groundwater samples were found to exceed the WHO standard for drinking water of As $(10 \mu \mathrm{g} / \mathrm{L}), 74 \%$ to exceed the standard for $\mathrm{Mn}(0.05 \mathrm{mg} / \mathrm{L})$, and $50 \%$ that for $\mathrm{Fe}(0.3 \mathrm{mg} / \mathrm{L})$. These data were shown in Fig. 5 and Table 2 (Hoang et al. 2010). As levels ranged from 0.1 to $1351 \mu \mathrm{g} / \mathrm{L}, \mathrm{Fe}$ concentrations from 0.01 to $38 \mathrm{mg} / \mathrm{L}$, and $\mathrm{Mn}$ from 0.01 to $14 \mathrm{mg} / \mathrm{L}$ (Hoang et al. 2010). Arsenic was found in groundwater in wells less than 60-70 $\mathrm{m}$ deep in this region (Buschmann et al. 2008). High Fe concentrations were found in the groundwater of Dong Thap, Kien Giang, and Long An provinces. High levels of As were found primarily in An Giang and Dong Thap provinces, with almost $50 \%$ of groundwater samples exceeding the WHO standard for As $(10 \mu \mathrm{g} / \mathrm{L})$. In addition, Mn concentrations exceeded the WHO standard of $0.05 \mathrm{mg} / \mathrm{L}$ in approximately $72 \%$ of samples from An Giang and $64 \%$ of samples from Dong Thap. Consumption of untreated groundwater in these two provinces could be exposing nearly two million people to the risk of chronic arsenic poisoning. In

Table 2 The percentage of groundwater samples exceeding the WHO standard (Hoang et al. 2010)

\begin{tabular}{lllll}
\hline \multirow{2}{*}{ Element } & \multicolumn{4}{l}{ Percentage exceed the standard (\%) } \\
\cline { 2 - 5 } & An Giang & Dong Thap & Kien Giang & Long An \\
\hline As (10 ppb) & 43 & 38 & 24 & 12 \\
Mn (0.05 ppm) & 87 & 69 & 66 & 81 \\
Fe (0.3 ppm) & 13 & 54 & 55 & 71 \\
\hline
\end{tabular}


addition, the excessive intake of manganese can result in developmental problems in children.

Well depth and distance from the Mekong River are the primary factors determining the levels of As in groundwater, particularly in An Giang and Dong Thap. In An Giang, As levels in samples taken within $2 \mathrm{~km}$ of the Mekong River were nearly $1000 \%$ greater than those in samples taken at distances beyond $2 \mathrm{~km}$. Samples taken within $10 \mathrm{~km}$ had average As concentrations of $64 \mu \mathrm{g} / \mathrm{L}$, while samples taken at distances of more than $10 \mathrm{~km}$ had an average concentration of $8 \mu \mathrm{g} / \mathrm{L}$. In An Giang, shallow wells (less than $60 \mathrm{~m}$ in depth) had As concentrations of $115 \mu \mathrm{g} / \mathrm{L}$, while deeper wells had an average of only $19 \mu \mathrm{g} / \mathrm{L}$. In Dong Thap, the equivalent figures were $63 \mu \mathrm{g} / \mathrm{L}$ for shallow wells (less than $70 \mathrm{~m}$ deep), and $3 \mu \mathrm{g} / \mathrm{L}$ for deeper wells. Another issue directly impacting the health of people relying on groundwater is urban runoff and pollution from municipal wastewater. Groundwater samples taken from wells in Can Tho, the largest urban area in the Mekong Delta contain high levels of total coliforms. It is therefore very important to analyze the quality of groundwater in the Mekong River Delta (Nguyen et al. 2009).

Sedimentation in the delta began with the deposition of silt carried by the river during the transition from the Pleistocene to the Holocene. The sediments in the Mekong River Delta are high in organic compounds which create anoxic conditions that may promote the reduction of dissolved iron(hydro)oxides and cause the release of arsenic. There is a need for increased awareness about the potential health impacts, especially the co-contamination involving multiple toxic elements. In the early Holocene, fluvial deposits displaced tidal deposits as the primary source of sedimentation, resulting in an outward movement of the coastline (Berg et al. 2007). Groundwater in the lower Mekong Delta is highly saline with $4 \mathrm{~g} / \mathrm{L}$ total dissolved solids (TDS). Shallow groundwater has been exploited as a drinking water source by the rural population as a replacement for surface water, which is contaminated by microbes. Other heavy metals such as $\mathrm{Cd}, \mathrm{Ni}, \mathrm{Pb}$, and $U$ are known to cause numerous health problems such as DNA damage, cancer, and disorders of the central nervous system. Because $\mathrm{Ni}, \mathrm{Pb}$, and $\mathrm{Cd}$ exceeded the WHO standard around $\sim 1 \%$, they are not likely to have a significant public health impact. Uranium, however, can damage the kidneys and is also deposited on bone surfaces, where it emits alpha radiation and releases highly toxic decay products such as radon (Berg et al. 2007).

Comparison with other countries in the world, the As contamination in groundwater in Vietnam is quite high. It was estimated that around 150 million people in the world are probably affected by arsenic contamination in groundwater, especially in some Asian country as China, India, and Bangladesh (Ali et al. 2012). As was found in shallow tubewells in the low-lying Mekong Delta at Prey Vêng province, Cambodia. The As contamination in wells at this region were 100 times higher than the WHO standard with maximum concentration of $1052 \mu \mathrm{g} / \mathrm{L}$, nearly the same level with Arsenic contamination in Mekong delta in the south of Vietnam, while much lower compare with the north of Vietnam (O'Neill et al. 2013). The Jianghan Plain in China has $87 \%$ of the groundwater in wells with depths of 5-230 m containing As level at 10-2330 $\mu \mathrm{g} / \mathrm{L}$ (Xiaoming et al. 2017). In West Bengal of India, $48.1 \%$ of groundwater contains As above the WHO standard and $23.8 \%$ were above the Indian standard of $50 \mu \mathrm{g} / \mathrm{L}$. The wells in Holocene sediments at 35$45 \mathrm{~m}$ depth in Beldanga contain high As concentrations at 10 $4622 \mu \mathrm{g} / \mathrm{L}$ (Harshad et al. 2017). A recent study in the Kolkata, India analyzed 262 groundwater samples in 144 wards and reported that 100 wards in alarming arsenic contamination. About 51 wards $(35.4 \%)$ have arsenic concentration above the Indian standard of $50 \mu \mathrm{g} / \mathrm{L}$ while 49 wards got arsenic level 11-50 $\mu \mathrm{g} / \mathrm{L}$. As daily intake was estimated $0.95 \mu \mathrm{g} / \mathrm{kg}$ from drinking water and the cancer risk was 1425/106 (Dipankar et al. 2017). Based on studies conducted in the Brahmaputra River, the As levels were found from 0.07-0.60 $\mu \mathrm{g} / \mathrm{L}$ (Runti et al. 2015). As contamination in groundwater in the Nawalparasi District, Terai province in Nepal is a serious issue with the average concentration of $350 \mu \mathrm{g} / \mathrm{L}$, and $98 \%$ groundwater exceeded the WHO standard of $10 \mu \mathrm{g} / \mathrm{L}$. Higher As contamination at more than $400 \mu \mathrm{g} / \mathrm{L}$ in wells with depth at 18-22 and 50-80 m. As concentration over $500 \mu \mathrm{g} / \mathrm{L}$ in shallower wells were detected at Patkhauli, Mahuawa, Thulokunwar, and Goini (Akiko et al. 2014). In Mongolia, As concentrations are found in the range of 300$553 \mu \mathrm{g} / \mathrm{L}$ at the $\mathrm{SO}_{4}{ }^{2-}$ reduction stage, possibly results reduction of Fe oxide minerals from $\mathrm{HS}^{-}$(Yongfeng et al. 2017). High As levels was found in bedrock aquifer in western Quebec, Canada with more than half of the 59 bedrock wells exceed the WHO standard of $10 \mu \mathrm{g} / \mathrm{L}$ with As concentration ranges from 1.1-263.3 $\mu \mathrm{g} / \mathrm{L}$ (Raphaël et al. 2017). The As contamination in aquifers groundwater of Pliocene terrestrial layers is a significant issue in Sarkisla (Turkey) with concentration up to $345 \mu \mathrm{g} / \mathrm{L}$ and the average of $60.38 \mu \mathrm{g} / \mathrm{L}$ (Celalettin et al. 2013). As also was found in the range of 0 $180 \mu \mathrm{g} / \mathrm{L}$ from 992 drinking water samples in households of New Hampshire, USA. Significantly arsenic in the domestic drilled bedrock wells more than water from municipal sources (Qiang et al. 2009). Middleton et al. 2016 reported that 5\% private water supplies of 497 wells in Cornwall, South West England exceeded the WHO As standard of $10 \mu \mathrm{g} / \mathrm{L}$.

\section{Conclusions}

Concentrations of heavy metals such as As, Fe, and $\mathrm{Mn}$ in groundwater from the Red River and Mekong River Deltas exceed WHO drinking water guidelines, putting at risk the millions of Vietnamese people relying on groundwater in 
these regions as sources of drinking water. This situation suggests solution for drinking water suppliers together with efficient water treatment technologies for groundwater or alternative drinking water sources such as surface water or tap water. Vietnam has an expanding population and growing economy, and is undergoing rapid industrialization and urbanization. It is of the utmost importance that good strategies be developed for the management of safe drinking water for both public and private supply, in the cities as well as the countryside. Educating residents of rural areas to understand the effects of contaminated drinking water on their health is essential. A long-term water quality monitoring program with more frequent testing should also be considered.

\section{References}

Agusa T, Kunito T, Fujihara J, Kubota R, Minh T, Trang P, Iwata H, Subramanian A, Viet P, Tanabe S (2006) Contamination by arsenic and other trace elements in tube-well water and its risk assessment to humans in Hanoi, Vietnam. Environ Pollut 139:95-106

Agusa T, Kunito T, Minh T, Trang P, Iwata H, Viet P, Tanabe S (2009) Relationship of urinary arsenic metabolites to intake estimates in residents of the Red River Delta, Vietnam. Environ Pollut 157: 396-403

Akiko N, Kiyoshi K, Uddin S, Masakazu T (2014) Geochemical assessment of arsenic contamination in well water and sediments from several communities in the Nawalparasi District of Nepal. Environ Earth Sci 72:3269-3280

Ali I, Khan TA, Asim M (2012) Removal of arsenate from groundwater by electrocoagulation method. Environ Sci Pollut Res 19(5):16681676

Berg M, Stengel C, Trang P, Viet P, Sampson M, Leng M, Samreth S, Fredericks D (2007) Magnitude of arsenic pollution in the Mekong and Red River deltas - Cambodia and Vietnam. Sci Total Environ 372:413-425

Berg M, Tran H, Nguyen T, Pham H, Schertenlei R, Giger W (2001) Arsenic contamination of groundwater and drinking water in Vietnam: a human health threat. Environ Sci Technol 35:2621-2626

Berg M, Trang P, Stengel C, Buschmann J, Viet P, Dan N, Giger W, Stuben D (2008) Hydrological and sedimentary controls leading to arsenic contamination of groundwater in the Hanoi area, Vietnam: the impact of iron-arsenic ratios, peat, river bank deposits, and excessive groundwater abstraction. Chem Geol 249:91-112

Buschmann J, Berg M, Stengel C, Winkel L, Sampson M, Trang P, Viet P (2008) Contamination of drinking water resources in the Mekong delta floodplains: arsenic and other trace metals pose serious health risks to population. Environ Int 34:756-764

Celalettin S (2013) Assessment of naturally occurring arsenic contamination in the groundwater of Sarkisla Plain (Sivas/Turkey). Environ Earth Sci 68:691-702

Chau G, Sebesvari Z, Amelung W, Renaud G (2015) Pesticide pollution of multiple drinking water sources in the Mekong Delta, Vietnam: evidence from two provinces. Environ Sci Pollut R 22:9042-9058

Dipankar C, Bhaskar D, Mohammad R, Bishwajit N, Arup P, Mrinal S, Sad A, Amir H, Uttam C, Bhajan B, Khitish S, Dutta R (2017) Arsenic in groundwater of the Kolkata Municipal Corporation (KMC), India: critical review and modes of mitigation. Chemosphere 18:437-447
Duong H, Berg M, Hoang M, Pham H, Gallard H, Giger W, Gunten U (2003) Trihalomethane formation by chlorination of ammoniumand bromide-containing groundwater in water supplies of Hanoi, Vietnam. Water Res 37:3242-3252

Editorial (2010) Arsenic in groundwaters of South-East Asia: with emphasis on Cambodia and Vietnam. Appl Geochem 23:2968-2976

Eiche E, Neumann T, Berg M, Weinman B, Geen A, Norra S, Berner Z, Trang P, Viet P, Stuben D (2008) Geochemical processes underlying a sharp contrast in groundwater arsenic concentrations in a village Red River delta, Vietnam. Appl Geochem 23:3143-3154

Guillot S, Chakraborty S, Gajurel A, Upreti B (2008) Comparison of arsenic concentrations in simultaneously-collected groundwater and aquifer particles from Bangladesh, India, Vietnam, and Nepal. Appl Geochem 23:3244-3251

Jessen S, Larsen F, Postma D, Viet P, Ha N, Nhan P, Nhan D, Duc M, Hue N, Huy T, Luu T, Ha D, Jakobsen R (2008) Palaeo-hydrogeological control on groundwater as levels in Red River delta, Vietnam. Appl Geochem 23:3116-3126

Harshad K, Natalie M, Karen J, Saugata D (2017) Contrasting dissolved organic matter quality in groundwater in Holocene and Pleistocene aquifers and implications for influencing arsenic mobility. Appl Geochem 77:194-205

Hoang T, Bang S, Kim K, Nguyen M, Dang D (2010) Arsenic in groundwater and sediment in the Mekong River delta, Vietnam. Environ Pollut 158:26-30

Larsen F, Pham N, Dang N, Postma D, Jessen S, Pham V, Nguyen T, Trieu H, Tran L, Nguyen H, Chambon J, Nguyen H, Ha D, Hue N, Duc M, Refsgaard J (2008) Controlling geological and hydrogeological processes in an arsenic contaminated aquifer on the Red River flood plain, Vietnam. Appl Geochem 23:3099-3115

Lawati W, Rizoulis A, Eiche E, Boothman C, Polya D, Lloyd J, Berg M, Aguilar P, Dongen B (2012) Characterisation of organic matter and microbial communities in contrasting arsenic-rich Holocene and arsenic-poor Pleistocene aquifers, Red River Delta, Vietnam. Appl Geochem 27:315-325

McArthur J, Sikdar P, Hoque M, Ghosal U (2012) Waste-water impacts on groundwater: $\mathrm{Cl} / \mathrm{Br}$ ratios and implications for arsenic pollution of groundwater in the Bengal Basin and Red River Basin, Vietnam. Sci Total Environ 43:390-402

Middleton S, Watts M, Hamilton E, Ander E, Close R, Exley K, Crabbe H, Leonardi G, Fletcher T, Polya D (2016) Urinary arsenic profiles reveal exposures to inorganic arsenic from private drinking water supplies in Cornwall, UK. Sci Rep 6:25656

Minh L, Josette G, Gilles B, Didier O, Julien N, Quynh L, Thai T, Anh L (2010) Hydrological regime and water budget of the Red River Delta (Northern Vietnam). J Asian Earth Sci 37:219-228

Moglia M, Neumann L, Alexander K, Nguyen M, Sharma A, Cook S, Trung N, Tuan D (2012) Application of the Water Needs Index: Can Tho City, Mekong Delta, Vietnam. J Hydrol 468:203-212

Nguyen K, Itoi R (2009) Source and release mechanism of arsenic in aquifers of the Mekong Delta, Vietnam. J Contam Hydrol 103:58 69

Nguyen V, Bang S, Viet P, Kim K (2009) Contamination of groundwater and risk assessment for arsenic exposure in Ha Nam province, Vietnam. Environ Int 35:466-472

Norrman J, Sparrenbom C, Berg M, Nhan D, Nhan P, Rosqvist H, Jacks G, Sigvardsson E, Baric D, Moreskog J, Ringdahl H, Hoan N (2008) Arsenic mobilisation in a new well field for drinking water production along the Red River, Nam Du, Hanoi. Appl Geochem 23:31273142

O'Neill A, Phillips H, Kok S, Chea E, Seng B, Sen B (2013) Arsenic in groundwater and its influence on exposure risks through traditionally cooked rice in Prey Vêng Province, Cambodia. J Hazard Mater 262:1072-1079

Qiang Y, Hun J, Charles C, Robert M, Marc L, Daniel L, Heidi C, Hilary T, Yan Z (2009) Spatial pattern of groundwater arsenic occurrence 
and association with bedrock geology in greater Augusta, Maine. Environ Sci Technol 43(8):2714-2719

Raphaël B, Vincent C, Eric R, Mostafa B (2017) Mobility and speciation of geogenic arsenic in bedrock groundwater from the Canadian Shield in western Quebec, Canada. Sci Total Environ 574:509-519

Runti C, Pallavi S, Chandan M, Hari S (2015) Evaluation of the processes controlling arsenic contamination in parts of the Brahmaputra floodplains in Assam, India. Environ Earth Sci 73:4473-4482

Smedle P, Kinniburgh D (2002) A review of the source, behaviour and distribution of arsenic in natural waters. Appl Geochem 17:517-568

Postma D, Jessen S, Hue N, Duc M, Koch C, Viet P, Nhan P, Larsen F (2010) Mobilization of arsenic and iron from Red River floodplain sediments, Vietnam. Geochim Cosmochim Acta 74:3367-3381

Postma D, Larsen F, Hue N, Duc M, Viet P, Nhan P, Jessen S (2007) Arsenic in groundwater of the Red River floodplain, Vietnam: controlling geochemical processes and reactive transport modeling. Geochim Cosmochim Acta 71:5054-5071
Thuy N, Akira K, Thanh T, Hideo A, Naoko N, Romeo G, Duong B (2015) Identification of spatio-seasonal hydrogeochemical characteristics of the unconfined groundwater in the Red River Delta, Vietnam. Appl Geochem 63:10-21

WHO (2005) Guidelines for drinking water quality, second edn. World Health Organization International Program on Chemical Safety, Geneva, pp 156-167

Xiaoming C, Xian-Chun Z, Jianing W, Yamin D, Teng M, Guoji E, Yao M, Ye Y, Hao L, Yanxin W (2017) Microbial communities involved in arsenic mobilization and release from the deep sediments into groundwater in Jianghan plain, Central China. Sci Total Environ 579:989-999

Yongfeng J, Huaming G, Beidou X, Yonghai J, Zhuo Z, Rongxiao Y, Weixiong Y, Xiaolei X (2017) Sources of groundwater salinity and potential impact on arsenic mobility in the western Hetao Basin. Inner Mongolia, Sci Total Environ 601:691-702 